\title{
The distinction of excellent students in the
}

Portuguese state school as a strategy of educational marketing accountability

\section{Leonor L. Torres, José A. Palhares \& Almerindo J. Afonso}

Educational Assessment, Evaluation and Accountability

International Journal of Policy, Practice and Research

ISSN 1874-8597

Educ Asse Eval Acc

DOI 10.1007/s11092-019-09298-4

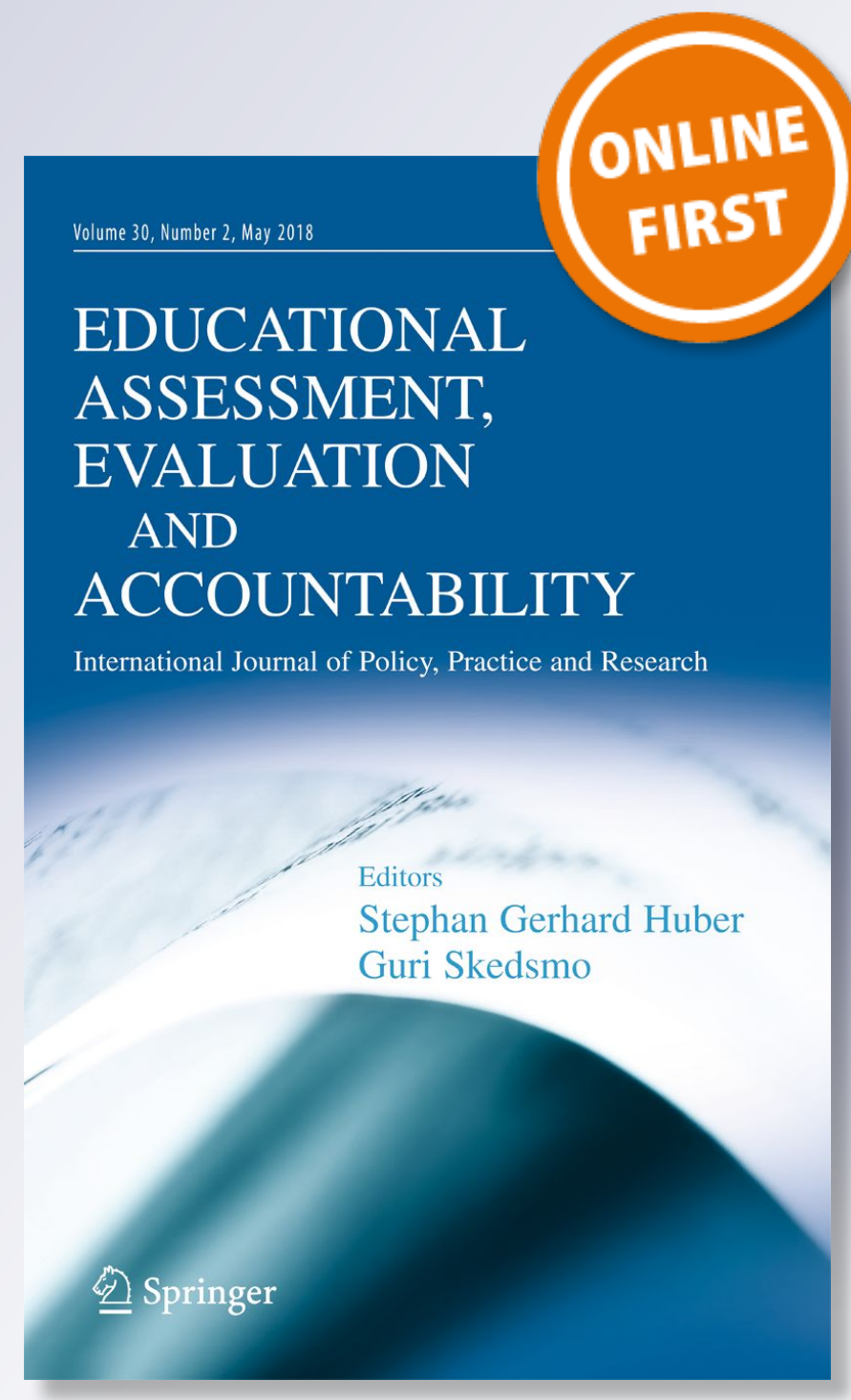

黛 Springer 
Your article is protected by copyright and all rights are held exclusively by Springer Nature B.V.. This e-offprint is for personal use only and shall not be self-archived in electronic repositories. If you wish to self-archive your article, please use the accepted manuscript version for posting on your own website. You may further deposit the accepted manuscript version in any repository, provided it is only made publicly available $\mathbf{1 2}$ months after official publication or later and provided acknowledgement is given to the original source of publication and a link is inserted to the published article on Springer's website. The link must be accompanied by the following text: "The final publication is available at link.springer.com". 


\title{
The distinction of excellent students in the Portuguese state school as a strategy of educational marketing accountability
}

\author{
Leonor L. Torres ${ }^{1}$ (D) - José A. Palhares ${ }^{1} \cdot$ Almerindo J. Afonso $^{1}$
}

Received: 6 April 2018 / Accepted: 23 April 2019/Published online: 11 May 2019

(C) Springer Nature B.V. 2019

\begin{abstract}
The mechanisms of academic distinction of the best students, such as the Honours Boards of Excellence and Value, emerge in Portuguese state schools as important institutional management strategies for promoting the school image and attracting the best students. This is what the authors propose to discuss, and that they identify as being a new form of accountability - the educational marketing accountability. In other words, at the theoretical level, this article intends to explore the relationship between the results obtained by students, the promotion of academic excellence and a new form of accountability in the Portuguese non-higher education system. The empirical focus was the analysis of the institutional marketing strategies of management adopted by the head teachers and their impact on the school choice by the students. The authors used data from a questionnaire applied to students from four secondary schools who were asked to complete, interviews with head teachers and content analysis of documents from most Portuguese schools with academic distinction rituals. The research confirms the obsessive centrality of academic results in the daily management of schools; simultaneously, the distinction of the best students is an institutional marketing strategy that influences the choice of school, projects a desired social image and further reinforces the performance and leadership style of the head teachers.
\end{abstract}

Keywords Marketing accountability · Management school excellence - Academic results · Academic distinction

Leonor L. Torres

leonort@ie.uminho.pt

José A. Palhares

jpalhares@ie.uminho.pt

Almerindo J. Afonso

ajafonso@ie.uminho.pt

1 Research Centre on Education (CIEd), Institute of Education of University of Minho, Campus de Gualtar, 4710-057 Braga, Portugal 


\section{Introduction}

Having failed to achieve some of the democratic and egalitarian challenges of education, which were posed with urgency to the Portuguese society after the revolution of April 1974, in the last two decades, the educational system has begun to move towards more (re)meritocratic and performative logics. The democratisation of education intended to open the school to all at a time when it was found that more than $30 \%$ of the Portuguese population was illiterate. Since then, access has been universalized, but significant social and educational cleavages have continued to persist within the educational system. In the long authoritarian regime that preceded the democratic revolution, meritocracy was a useful belief, which (supposedly) justified the access and success of some individuals to dominant political and economic circles, and thus legitimised, ideologically, the selective exercise of important functions in public administration. In Portuguese schools, meritocracy was very close to the conception criticised by Michael D. Young (2008, p. xiii), traduced by "the proposition that I.Q. + effort $=$ merit". As the author ironically pointed out, in a meritocratic society "individual merit should be the only test that should be applied" and people are assigned to classes according to "their achievement rather than ascribed by their birth" (p. xiii). These assumptions are clearly called into question by the democratisation of the regime, completely averse to any "aristocracy of talent" until, at the end of the 1990s, its presuppositions resurfaced by the hand of ex-left-wing intellectuals, in some cases reconverted to neoconservative and neoliberal orientations. This is what we call (re)meritocratization of the educational system, alongside the unfinished project of a truly democratic school. It can be said that today we update what was written two decades ago about the emergence of a "tension between the democratic school and the meritocratic school - a tension that was fed by the gradual predominance of the needs of the accumulation process (requiring a more elitist system, a more instrumental curriculum and an early recognition of the capacities) against the accumulation context, more consistent with equal opportunities" (Afonso 1998, p. 278).

There are many models and relatively distinct concepts of accountability (see, for example, $\mathrm{Ng}$ 2010), in the Portuguese context, and in many other countries in the last decades. The pressure for the introduction of new mechanisms of accountability in the education system derives mainly from the implementation of external national or international examinations and standardised tests, and the correlative scrutiny that stems from the publication of rankings based on the results obtained in these systems of assessment and evaluation (Meuret 2012; Dutercq and Maroy 2014; Hardy 2015). In the dawn of a new public management (see, among others, Verger and Curran 2014), adjustment devices of the quality of state schools have also emerged, namely the programme for the external evaluation of schools, with the scale of the academic results taking centre stage (here as well). So, between civil society and the market, which pressured the emergence of rankings supported by the media (Baroutsis 2016), and the State (who set in motion central devices for the supposed evaluation of the system's efficiency and effectiveness), mechanisms of accountability were created that are not unrelated to the inevitable comparison with the new educational market headed by private and cooperative education schools (charter schools or academies and free schools).

If the impact of the rankings in itself contained publicity elements of the performance of schools at the external level (national, regional and local), it was, however, 
also necessary to highlight the academic performance of students at the internal and local level. The ritualisation of the school excellence of students (e.g. Honours Boards of Excellence and Value and public ceremonies in the school and community) is now an additional institutional marketing strategy, considered an important part in attracting the best students, against a backdrop of sharp demographic decline of the Portuguese school age population. The place of the school in the rankings, the boards and the rituals of academic distinction of the best students, and the placement of these students in socially more prestigious higher education courses emerge as the most consistent indicators for the promotion of the social image of the school institution, all this having school results as a common denominator. This school image, anchored in performative indicators, is increasingly used as a management strategy to attract the best students and simultaneously as a reference for families and students (Antunes and Sá 2010) to choose the school that best fits their life project.

In this text, we seek to understand the relationship between the expansion of the meritocratic culture in the Portuguese educational system and the development of governance and management strategies focused on the performance of the best students. These strategies tend to introduce new contours of institutional marketing centred on the promotion and ritualisation of academic excellence. At a time when the unipersonal management model of schools (centred on the role of the head teacher) assumes new forms of accountability, academic ritualisation and distinction emerge as internal strategies of school marketing, mainly due to increasingly higher external pressures from the strongly competitive environments. Therefore, the guiding question in this text can be formulated in the following terms: how are the strategies of distinction and ritualisation of the best students generating new forms of accountability congruent with the assumptions of the new public management? More so, what strategies do the head teachers adopt to keep their school attractive within the community and at the same time comply with the "contract" with the central administration of the Portuguese education system? We will try to answer these questions from three perspectives: (i) the formalisation and ritualisation of academic distinctions in Portuguese secondary schools, resulting from the analysis of the main guiding documents of school organisations; (ii) the management strategies used by the head teachers in order to build a social image of school, collected through semi-structured interviews; and (iii) the school choices identified in the responses given by the students in a questionnaire survey.

\section{Accountability and school excellence}

Considering different countries and analysing their educational agendas, we can see that the statements, legal regulations and institutional and organisational practices are becoming more common, in what concerns, directly or indirectly, the policies, systems or models of accountability (Parcerisa and Verger 2016). This is not a finding without precedent, given that, in many cases, the policies of accountability can be thought of in a certain diachrony, where we can find identifiable and reconstitutable facts and reasons, and where it is possible to realise specific features or similarities, as well as differences, when referenced to the current historical conjuncture. So, if, for example, we consider the Portuguese context and go back half a century, we can see that the authoritarian and non-democratic nature of the State and its bureaucratic administrative 
machine imposed an accountability model. This model was translated mainly by maximising the assessment component as a central control device (an essential function, for example, of the old, non-standardised national examination) and by forms of hierarchical and coercive accountability, together with devices to monitor and maintain confidentiality. However, this scenario is radically incompatible with the right to information when facilitated by the transparency of procedures and the participation of citizens. With the democratisation of the country, the previous bureaucratic and authoritarian accountability model became fragmented into partial forms of accountability. These, although supported by a legal bureaucratic rationality, became permeable, separately and according to the services and sectors of the State and public administration, to the values of transparency, democracy and participation, albeit with very different degrees of intensity, and not always consolidated (Nunes et al. 2003; Afonso 2010a, 2014).

The gradual penetration of principles of the new public management among many other factors induced or hastened the redefinition of the role of the State and the reconfiguration of the traditional boundaries between the public and private sectors (Verger and Normand 2015; Derouet et al. 2015). In some cases, these came closer to already established models and, in other cases, were simply new forms of accountability, which translate, in this new context, into dynamics that gradually emerged, either brought on by specific political guidelines or pushed by the schools and/or school clusters themselves. Examples of this are the current model of external evaluation of schools, the current model of administration of schools, the school rankings based on the results of standardised tests, the devices to academically distinguish the best students, and the sophistication of the mechanisms for the management of the school's social image. In fact, there are today in the Portuguese educational system models and partial forms of accountability of a managerial, bureaucratic, social, market and community nature that result from different visions and appropriations of all the actors and school and non-school instances, which hinders the summary of this hybridity. If, as we hope, the challenge is the analysis of possible (dis)articulations and (in)congruencies between conceptions of school excellence and partial models and forms of accountability, the task becomes more difficult, even though it is also very interesting from the sociological point of view.

In an exploratory exercise, it would be interesting to start from the following finding: in the authoritarian regime in force prior to April 1974, state schools in Portugal publicised excellence considering not only the academic performance of students but also the values, attitudes and behaviours. In this highly centralised and panoptic political system, the dominant accountability model within the education system was the bureaucratic and hierarchical model. This model also included a socio-familial dimension, in a time when the excellent students were awarded and these distinctions were only known within the school community and local environment. On the other hand, in the context of the representative democracy regime, but with growing influence from neoliberal and neoconservative agendas, the valuation and publicising of excellence re-emerges, in many situations, based exclusively and very narrowly on the academic performance of students. In this latter case, the partial forms of accountability translate or result from the hybrid interpenetration of the managerial, market (or quasimarket), community and social or active citizenship dimensions. If, on the contrary, we think from a purposeful perspective-one that advocates the construction of 
multidimensional school excellence, based on the promotion of the overall success for all with justice and equity, a more consistent system of accountability would have to mainly articulate dimensions of the professional, the community and the social or active citizenship models (Afonso 2010b).

With the new wave of national examinations as (further) control devices, and the adoption of other forms of comparative standardised assessment, mechanisms of academic distinction of the best students begin to proliferate in Portuguese state schools and/or school clusters, among which the honours boards of excellence and value stand out. Moreover, this trend is not exclusive to the Portuguese reality, being an educational phenomenon observed on a global scale, as demonstrated in the study of Torres and Quaresma (2017). In this context, we can now speak of the resignification of another form of accountability (which, although customary in organisations of a different nature, is only now starting to spread to state schools), which we propose here to call educational marketing accountability. That is, a model of accountability, which, as a result of selective practices of assessment, expands the social exposure of the best academic results, with the aim of promoting the public image of schools and, thus, increase the demand for new student enrolments while maintaining the places in the institutional rankings. It is therefore something more than a simple strategy for the advertising or publicity of education (educational marketing), because it serves objectively to give an account (answerability) of school work, with specific consequences in organisational terms, as well as implications for the definition of personal and academic paths.

This other form of accountability - marketing accountability — originates in the school itself and explicitly aims at the wide publicity of its excellent results, and the induction of demand through an educational offer of supposed excellence. The widespread publicity of school results, especially national exams, has been propelled by the mass media through the establishment of school rankings. This constitutes an external pressure which disseminates a school image - itself based on school results - with which managers (head teachers and other school structures) cannot interfere. However, when this publicity originates from the interior and with the schools' initiative- in the use of their margins of relative autonomy-we are confronted with a new reality. In addition to seeking to generate market effects in the educational supply and demand dynamics, educational marketing accountability also seeks to legitimise the action of the governing bodies of the school, build a school culture and its prestige in the community, increase a sense of belonging and self-esteem (between teachers, students and non-teaching staff), generate socialising effects, among other aspects. Therefore, in our perspective, it is not just a matter of marketing because schools and/or school clusters, when choosing to distinguish excellence, are also giving this action a symbolic and identity meaning (Torres 2014, 2015). This distinction of excellence also serves as a reference for pedagogical action focused on obtaining results agreed with the central authority and regularly scrutinised by the inspection mechanisms and by the community. What is relatively new in Portugal is that the awards of academic distinction are now widely publicised. As a consequence, school managers trigger around these prizes other rituals that converge and legitimise their school leadership style. We believe, therefore, that this set of procedures - which include evaluation, answerability and its consequences (prizes) - are related to marketing accountability.

Finally, if we consider a complete model of accountability when the pillars of the evaluation, answerability and responsibilization are articulated in some way, we often 
find that the nature of the responsibilization or enforcement (that is, if the expected consequences are negative or positive) tends to become the predominant criterion for characterising a particular model. In this sense, the most usual designations oscillate between soft accountability and hard accountability models. In our research, we understand that the emergence of an educational marketing accountability model is also a form of soft accountability, since school managers aim to promote, as a desired consequence, a positive image of the school to attract the best students (as producers of excellent academic results).

\section{The return of the meritocratic ideology}

Since the 1980s, academic excellence has become a recurring theme in political discourses on education, assuming an increasing importance when associated with the concerns relating to the quality, competitiveness, merit and effectiveness of the educational system. At the European level, the priority tended to focus on the development of competitive educational systems, regulated by the economic interests and needs of the market and by forms of effective governance and consistent performance (Ball 2000; Ward 2012). In political orientations mainly supported by certain sectors of the ruling classes and the middle classes, the political emphasis placed on the production of educational outcomes was accompanied by the pressure for the reconfiguration of the mission of state schools, progressively more hostage of individual performance and accountability based on the publication of evaluation results and standardised tests (meritocratic mandate) and less involved in the consolidation of the democratisation of school processes (democratic mandate).

As some countries have started to combat school failure and dropout, the demands placed on the production of academic excellence were intensified, in a clear adherence to the cult of meritocracy (McNamee and Miller Jr 2004; Dench 2006). Studies on the meaning of merit and the role of schools in its construction multiplied, arriving at different positions regarding the centrality of the meritocratic ideology in the processes of education regulation (Daverne and Dutercq 2008; Duru-Bellat 2009; Michaud 2009; Dutercq and Daverne 2009; Tenret 2011; Daverne and Dutercq 2013). On the other hand, the debate expands internationally in order to assess the effects of this agenda in the elitisation processes of education (Van Zanten et al. 2015; Blackmore 2016; Maxwell and Aggleton 2016). Inserted in this broader framework, the Portuguese education system presents some difficulties in reconciling the mandates that are now required to it. Unlike many countries in Europe, the Portuguese state school is characterised by quality and performance standards that are not very different from private education. State schools outnumber private schools, approaching the same philosophy of the comprehensive schools, assuming several educational mandates - aimed to the democratisation of educationand being inclusive of all socio-economic classes.

Recurrent in the political debate, the discussion about school excellence in Portugal has had frequent translation in the media and was also included in some works of academic nature (Magalhães and Stoer 2002; Cortesão et al. 2007; Quaresma 2010; Palhares and Torres 2015; Torres and Quaresma 2017; Palhares and Torres 2017). From a political point of view, the values of excellence and merit were disputed by all political ideologies, including an avant-la-lettre discussion, carried out by both left- 
wing intellectuals and conservative politicians. Although the various political forces have captured the meritocratic ideology, seeming to be a consensual and shared model, the criteria deployed for the definition of excellence are very variable. On the one hand, the restrictive and unidimensional nature of school excellence, based on the "schooling of merit" (Tenret 2011), is questioned and, on the other hand, a more pluralistic perspective of excellence is advocated, which is considered to be more reconcilable with the democratic nature of state schools. The diversification of forms of excellence seems to constitute a new political concern in Portugal, with the redefinition of education for citizenship (Legislative Order no. 6173/2016 2016, of 10 May) and with the new competences inscribed in the new student's profile of compulsory schooling, as part of a process to promote autonomy and curricular flexibility (Legislative Order no. 5908/2017 2017, of 5 July).

Within a context increasingly marked by the principles of the new public management, educational guidelines aimed at producing measurable results are recurrent and multiply in various social and educational spaces and times, and under the aegis and impetus of several instances of national and international regulation. Figure 1 tries to flag some of the guidelines implemented and ongoing in Portuguese society. A first block of measures coming from the central administration (State) fall on the mandatory nature of national examinations at all levels of education, alongside the creation of the honour's boards of excellence, which came to be implemented in the vast majority of schools. In parallel with the implementation of the external evaluation programme of schools from 2006, we saw the change in powers of the local administration of schools, with the implementation of a single-person management model more consistent with forms of regulation typical of the new public management.

A second block of measures, driven by the community/civil society (namely by the pressure of families) and the market, emphasises the expansion of non-formal contexts of education with strong connections and articulations with formal education-for example, the articulation of music academies with state schools within the scope of musical and artistic education and the growth of the private tutoring market. The impact of the publication of educational outcomes is also noticeable in Fig. 1, either through the dissemination of school rankings based on the results of the national examinations or by the effect of participating in comparative international evaluations (Programme for International Student Assessment-PISA; Trends in International Mathematics and Sciences Study_-TIMSS; Progress in International Reading Literacy Study_PIRLS; among others).

\section{Methodological framework}

The empirical evidence uses data from a recently concluded research project on the construction of academic excellence in the Portuguese state school, anchored in a multiscale methodology that included two complementary approaches. The first, of an extensive and macro-analytical nature, is focused on the mapping of the policies and practices of academic distinction of the best students. We collected an extensive set of documentary information, which proved to be essential to understanding the real impact of the meritocratic ideology on the regulation of school life. We analysed the web pages of schools (school year 2013-2014), collecting in a first stage around 1500 


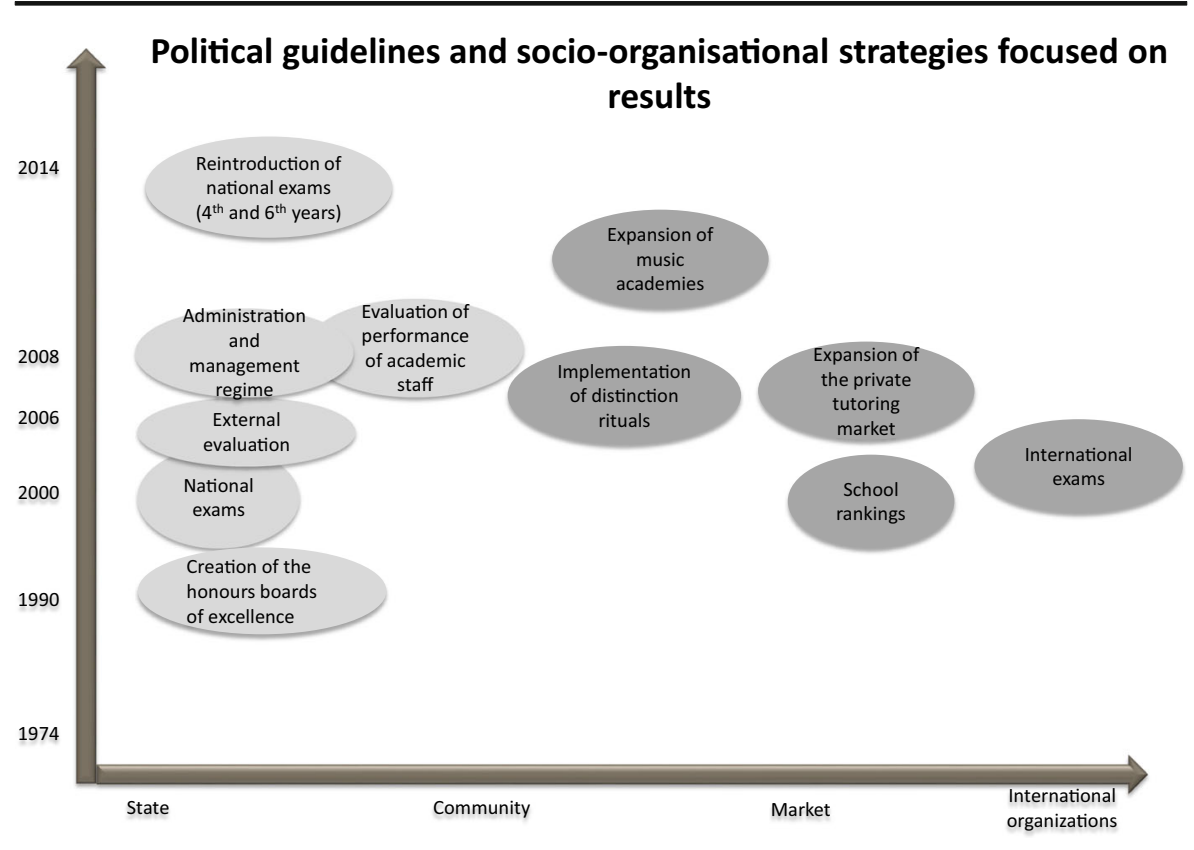

Fig. 1 Political guidelines and socio-organisational strategies focused on results. Program used: Microsoft PowerPoint for Mac 2011

structuring documents of school life, which were later the object of categorical content analysis (Bardin 1977) and statistical summary, supported by qualitative data analysis software NVivo 11.0. In addition to these documents, we also analysed the news published in the local media, the external evaluation reports and the rankings of the schools, available and advertised in leading newspapers of national reference. All this data collection supported the discussion presented in the next section of this paper about the rise of the rituals of academic distinction.

The second approach, of an intensive and meso-micro analytical nature, was based on four case studies developed in secondary state schools in the north and centre of Portugal, with similar characteristics (integrated or not in a school cluster, school well positioned in the national rankings of schools, school with implementation of honours boards of excellence). From the data collected in the aforementioned case studies, we selected for this paper information from semistructured interviews of head teachers and data from two questionnaire surveys administered to two student samples. The interviews - carried out at various moments in time and transcribed and analysed according to pre-defined categories - aimed to identify some dimensions related to the construction of the social image of the school. Regarding the questionnaire surveys, we elected as target population the universe of students with excellent performance (average classifications equal to and/or higher than 18 marks, on a scale of 0 to 20), in contrast with a representative sample of non-excellent students (with average performance below 18 marks). These students attend scientific-humanistic courses in secondary education corresponding to the 10th, 11th and 12th years of compulsory education. We applied two questionnaires (1022 students from 4 
schools) to these two types of students: (i) 200 questionnaires to the excellent students that correspond to all students at this level of performance (ii) and 822 questionnaires to non-excellent students, resulting from the extraction of a proportional stratified sample-30\% of all non-excellent students. We used in this text only the variables related to the school choice, confronting these with a set of independent variables regarding socio-economic class and academic performance with the intention of highlighting the way in which students evaluated their own school choice. This is further discussed in the last section of this article through a multiple correspondence analysis (optimal scaling procedure from IBM SPSS Statistics, 23.0). Privileging the subject's point of view, we tried to demonstrate the probable impact that the institutional marketing strategies exert in the construction of the school's image and choice.

This approach, centred on two institutional actors, focused, on the one hand, on the fact that the head teachers are invested in the role of promoting educational success and the need for accountability to the central administration and the community, and, on the other hand, on the fact that secondary school students have a relative degree of autonomy in their choice of school and scientific area (Vieira et al. 2013). With this degree of education being crucial for the access to higher education and to the most prestigious courses, the distinction of the best students in public rituals works as both a strategy for promoting the school image and the legitimisation of the political action of head teachers.

\section{Rituals of academic distinction as a marketing strategy}

A growing number of schools have been assuming academic excellence as one of the central goals of action. The inclusion of this mandate in the political-normative agenda of the school organisations is increasingly evident, although with different emphases, shades and meanings. From the point of view of the governance guidelines for education, the implementation and publication of rituals of academic distinction have been fostered by setting up the honours boards of value and excellence as mechanisms for the social and institutional visibility of "excellent students" or students with high performance in the cognitive, cultural, personal and social domains (Legislative Order no. $102 / 90$ n.d., of 12 September). In the same way, the "merit award" was legislated (Order no. 20513/2008 2008, of 5 August and Order no. 13173-C/2011 2011, of 30 September) and, more recently, the importance of academic performance was recognised in the Statute of Non-Higher Education Students (Law no. 51/2012 2012, of 5 September). This trend became more evident as schools were scrutinised for their academic results, simplifying the notion of excellence to measurable indicators, easily translated into higher grades of the evaluative scale. An excellent student came to be synonymous with high performance in the cognitive domain, although, in many situations, this label is conditioned by exemplary behaviours within its school institution.

The analysis of institutional websites and structuring documents (educational projects, internal regulations, plans of activities, political projects of the head teachers) of 335 state schools from the universe of 410 establishments with secondary education allowed us to conclude that a significant percentage ( $93 \%$ of the cases) of mechanisms 
of academic distinction were formally introduced. ${ }^{1}$ The content analysis performed also revealed that about 246 of these schools have adopted the "mixed academic distinction" (considering both the academic distinction based on results and the practice of certain values or behaviours). In turn, 61 educational establishments predicted the academic distinction focused exclusively on results, only 3 schools elected the attitudes and behaviours, while 19 schools did not provide any kind of academic distinction.

In any case, the boards of academic distinction based on academic results are most often publicised, without giving the same attention or focus to the honours boards of value (e.g. civic behaviour and citizenship) or other forms of award. Also, on analysing news published in the local media, we could see that schools distinguished, in public ceremonies, mainly students with the higher school averages. This was emphasised in the reports prepared by the external evaluation team of the Inspector General's Office of Education and Science under the item "recognition of the community". In $83 \%$ of the cases, a public ceremony of praise of the academic merit was held, in schools or not, with the involvement of teachers, the local community, families, representatives of local authorities and, in some cases, with the presence of the sponsors of the awards (companies, banks, groups of neighbours, friends and community leaders - e.g., Rotary Club). Usually, the echoes of these rituals are disseminated in the media and social media/networks and were even recorded in the yearbooks of schools and/or school clusters.

The data in Table 1, resulting from the further study of a sample of schools located in more densely populated pedagogical areas, confirm that the planned distinction does not coincide with the implemented distinction, with academic results remaining as the main distinction criterion. Two trends deserve particular attention: (i) the implementation of the "mixed academic distinction" is substantially lower than what was identified before in the formal plan (39\%) and (ii) the trend regarding the overvaluation of measurable results remains strong $(48 \%)$.

Effectively, the data show that school merit, strictly associated to results, prevails in the practices of academic distinction, reinforcing Stephen Ball's diagnosis (2000) when he states that "and in all this the demands of performativity dramatically close-down the possibilities for 'metaphysical discourses', for relating practice to philosophical principles like social justice and equity" (p. 8). In a society where the discourses of performance and competition are increasingly valued, the production and measurement of quantitative results have become a goal of certain ideological orientations for the education policies, as illustrated by Grek (2009) in the diagnosis she makes on the PISA studies adopted in Europe as " [...] a valuable source of data about the systems it is meant to govern" (p. 34). The adoption of measurable indicators, supposedly objectifiable and capable of being compared, has served the purposes of a logic of governance by numbers (Grek et al. 2009; Grek and Ozga 2010; Lawn 2011/2), which spread to the different levels of governance of education. In a pure logic of accountability, at the level of individual schools, strategies to give visibility to the performance levels have been implemented, of which the rituals and ceremonies around the consecration of excellence are a reflection. The right of students to see recognised their

\footnotetext{
${ }^{1}$ In the mapping that we performed for this research, we find a variety of designations relating to the mechanisms of academic distinction of merit and excellence in Portuguese schools: Honours boards of excellence, Honours boards of value, Merit grants, Special commendations, Endorsements of merit, Certificates of merit, Endorsements of excellence, Honourable mentions, Merit titles, Diplomas of merit, Diplomas of praise, Diplomas of honour, Honours boards of honour, Roll of honour, Honours boards of merit, Board of attendance, and Board of honourable behaviours.
} 
Table 1 Planned academic distinction and implemented academic distinction

\begin{tabular}{lllll}
\hline Type of academic distinction & $\begin{array}{l}\text { Formally } \\
\text { planned }\end{array}$ & $(\%)$ & $\begin{array}{l}\text { Effectively } \\
\text { implemented }\end{array}$ & $(\%)$ \\
\hline Academic distinction focused exclusively on results & 61 & 18.2 & 161 & 48.1 \\
Academic distinction focused exclusively on values/behaviours & 3 & 0.9 & 4 & 1.2 \\
Mixed academic distinction (results and values/behaviours) & 246 & 73.4 & 132 & 39.4 \\
No academic distinction & 19 & 5.7 & 30 & 9.0 \\
No information & 6 & 1.8 & 8 & 2.4 \\
Total & 335 & 100 & 335 & 100 \\
\hline
\end{tabular}

Source: Guiding documents of schools (2013/2014 school year), websites of schools and/or school clusters with secondary education, news published in the media, external evaluation reports and other documents

Program used: Microsoft Word for Mac 2011

"commitment in merit actions, including volunteering in favour of the community of which they are part or society in general, practiced at school or outside of it, and to be encouraged in this sense" (Law no. 51/2012, of 5 December), seems increasingly out of the scope of education priorities. The centrality of the examinations at the end of each education cycle has redirected everyday teaching in schools towards the achievement of academic performance goals by students. The completion of model tests and the implementation of the simulations of exam situations became a reality in many Portuguese schools, serving as a socialisation device in a performative culture and, at the same time, as a strategic mechanism for the timely detection of all those students who may possibly jeopardise the position of the school in a future ranking.

\section{Creation of the school image through results: the head teachers' perspective}

In the face of the pressure to produce results, school organisations have been adopting institutional marketing strategies with a view to project their image at the local and national level. The good academic performance of students, therefore, became the fundamental ingredient of the brand image, a sort of useful marketable product, susceptible of generating more and better audiences, resources and strategic advantages in the field of school management and leadership. The updating of the schools' websites began to receive more attention, as they are one of the main forms of communication, in addition to the development of editorial projects internal and external to the organisation. The resurgence of yearbooks and the revitalisation of school newspapers acquired a new central role as mechanisms for the promotion of school initiatives, while at the same time partnerships were expanded with the local media in order to guarantee spaces for dissemination. The cooption of the media strengthens the advertising strategy and is clearly reflected in the testimony of the head teachers of secondary schools interviewed (HT):

Also very important in this image are all the other circumstances in which the school appears as a relevant local key player, that is, each time that the school appears in the media or people talk about it, the school gets noticed for winning a 
prize, or a contest, for things that its students have achieved, and this seems to have an impact. And yes, then there is a strategy of promoting the image and selfpromotion that is not only of the school as an organisation, but also of the students themselves, the teachers, and the work they do (HT5).

Likewise, institutional communication as a reinforcement of the image and the collective identity is apparent in the concerns of one of the head teachers interviewed:

One of the things we did earlier, at the beginning of our work, particularly regarding the direction of the school, was to create our own communication outlets. I believe that this has had a very relevant strategic importance: the creation of the school newspaper and editorial activities, and a few years later, a very important project - the school yearbook. All this had as explicit objectives to create a school that needs to create and recreate itself and to permanently strengthen its position as an organisation, as a collective, as a collective identity (HT5).

More recently, the wide publicity of the results of access to higher education in several media outlets also serves to prove the success of the school in achieving its educational mission, often giving out the idea that this mission will be more effective if it is able to promote subsequent higher-level paths that are equally successful:

I must say that when the results of the access to higher education are out, for example, we publicise it, yes! We are keen to show these results to the school and the community, which, in essence, are the result of the academic path of our students (HT1);

The explicit actions to focus on the access to higher education has always been a deliberate strategy to promote the image of the school and say: please notice, this school is not an end in itself, not at all. This is a school that opens the way for longer academic paths, and very successful ones, and we have top examples of people who have now achieved a reputation at national and international level. We see here actions of almost institutional marketing in the construction and deconstruction of ideas related to the fatality of the context (HT5).

Also related with the "quality" of the results, the academic distinctions are clearly assumed as the brand image of the school, a ritual of consecration of the best students. The fieldwork demonstrated different forms of organising the ceremonies of consecration of the best students. But in many rituals, the speech of all actors involved (particularly the head teacher) emphasises and reinforces the role of the school in the construction of excellence and identity (Torres 2014, 2015). The unveiling of the board of excellence is a strong symbolic moment of enthronement of the best students before an auditorium full of families and local authorities and is later posted in the main entrance hall of the school for 12 months:

We do not post boards, or post names, but we talk about it and publicise the results (HT1);

The honours board of excellence is appealing and beyond being visually attractive, we have many students there that make the school proud and project a good 
image of the school. We have to project the school in the future. The honours board of excellence and all the promotion and projection measures of the school favour students, but also propel the school forward. It is a political and strategic issue for the school (HT2);

The pride and satisfaction it gives me to see students, parents and guests come to the school and look at that honours board of excellence, which is something remarkable with so many grades and figures, is very important; it strengthens, let us say, the head teacher's ego and I think the ego of all the people involved in the school (HT2).

As a corollary, the publication of the rankings acts as confirmation of the place of the school in the national scenario, regardless of the positioning of head teachers more or less favourable to the construction and public disclosure of sorted lists of schools:

Whenever the rankings and school results are published we put them up and make them public for students and teachers, clearly underlining the school results (HT2).

In a more sophisticated way, some schools use current and former students' success as a "calling card" for the school:

Our students are our school's best "calling card", they are the best promoters of our school. They promote it when they get good results, in their success in national competitions, when they give the impression of a quiet, orderly school, with citizens instead of just young people by projecting this image of responsible, attentive, interventive and disciplined persons. I think that all this promotes the school and brings us more students, it's a circle. (HT2).

People who were our students today have professional, social and institutional roles in society, they are people with a reputation in their professions, and have academic, professional and personal paths of great value. They regularly return to our school to give lectures and participate in conferences (HT5).

The recent intensification of the participation of local government in the educational decisions demands a strategic repositioning of schools at the level of the local space. Thus, the presence of school representatives at various events and educational and cultural initiatives begins to be seen by leaders as a contribution to the social projection of the work carried out:

The institutional presence of the school in external actions, from the most symbolic action, like an anniversary ceremony of the fire department or some other event at the town hall, went on to become systematic and compulsory. The school being present, being a relevant actor in local terms and in dynamics that are external to it, also strengthens the institutional image of the school. The school being invited and being present will lead to it being invited again to the next event (HT5).

Finally, the promotion of the school image has been seen as vital to the sedimentation of the organisational culture (Torres 2004) and, as such, it is believed that it should be a process in continuous reconstruction: 
The promotion of an image is not just for external purposes, it is also a selfimage, it is, in the end, an identity. We have created a concept and a set of branding and pure marketing actions, of creation of a brand, creation of a symbol, a logo, of a whole set of actions with the clear concern in mind of creating an image and introducing a new element. (HT5).

In the last decade, the governance model of Portuguese schools went through a significant change in political terms that led to the reintroduction of a "one-person" leadership model (head teacher) in place of a collegiate management, which had been in use from 1974 until 2008. This new management model has concentrated several powers on the head teacher, namely concerning the appointment of his team and pedagogical intermediate leaderships. However, being even more strengthened within the school, the head teacher remains hostage from outside (central administration and community). He is, therefore, more subject to the mechanisms of answerability and responsibility. Without much challenge (Torres et al. 2014), this transformation of the face of the school created the conditions to give visibility to the rules of new public management and the partial model of accountability. The commitments made by the head teacher to the school and the local community, formalised in the Intervention Project at the time of his or her candidacy, and the need to fulfil the contracts signed with the central administration make this leader hostage of objectifiable and measurable goals, in most cases related to the students' school success and the institution's performance level. In a scenario of demographic decline, rationalisation of resources and competition between schools, the head teacher's strategies focus also on the construction of a public image of the institution anchored in the academic outcomes of students. The media, responsible in a first instance for publicising the exam results and the corresponding school rankings, appears now as one of the central actors of an education (quasi) market, which either regulates the competitive position of the school at a local and national level or works as a space where episodes of daily school life converge, disputed by leadership when it comes to publicising the good practices of the institution. If we consider, for example, some of the specificities of the French educational system, where "accountability is more present in discourse than in education policy and its function is first of all rhetorical" (Dutercq 2016, p. 145), even so, the "obligation to perform" and a "legitimacy based on accountability" (Dutercq 2015, p. 44) also serve from our point of view to explain, at least in part, the action of Portuguese head teachers.

\section{The school choice in the students' perspectives}

The proximity of the school in relation to the family residence was for a long time the main criterion for the admission of students to Portuguese state schools. To overcome this constraint, many families strategically explored flaws in the law so that they could choose the school that was more adjusted to the interests of the life project of the student. With the introduction of the school clusters, organised in a sequential logic of the educational cycles, the matter of residence is no longer that urgent, even though it did make it possible to freely choose the institution and its educational project. More recently, the signing of school autonomy contracts with the central government opened 
the way to negotiate more flexible criteria for the admission of students, and the central role of merit as a selection criterion is already visible in many schools.

If the role of families can be decisive in the school choice in the elementary stages of education, the same does not seem to generally occur when we study the options of secondary education students, as we will observe further on (Fig. 2). As we saw in the previous point, the head teacher is emerging as a key agent in the articulation of the policy guidelines in the local context, governing and communicating in the education system through performance indicators; in turn, secondary education students (10th to 12th years of schooling) reappear as a target subject of the education policies, being encouraged to give their best in favour of their future, but also of the institution, particularly by obtaining good results in the national examinations at the end of the cycle that are decisive for their access to higher education. The distinction of the best students in rituals and public celebrations is founded on traditional meritocratic principles (skills or capabilities plus effort) and establishes a benchmark of the pedagogical and educational work of the institution, the latter being increasingly dependent on public performance indicators that can project it and ensure its survival in the educational market.

The timely definition of the life project seems to be crucial to outline the students' education and training path, particularly those who obtain high academic performance. When we asked students about the three main reasons for their choice of the school they attended in secondary education, their responses pointed, above all, to reasons of a performative, prospective and pedagogical nature (see Fig. 2), as demonstrated by preliminary studies carried out in the scope of this issue (Palhares and Torres 2015). The most consistent responses underlined the need for the school to have a demanding and quality education, in order to properly prepare students for higher education and to have a good learning environment, despite the first two reasons being mainly brought up by students with excellent performance. No less important, the proximity to the place of residence seems to be, also for the excellent students, a reason to consider, and this choice is associated to a climate of emotional stability favourable to their academic performance. On the other hand, students not belonging to the excellent group do not value these choices with the same intensity and conviction, adding differences of a relational, convivial and symbolic nature.

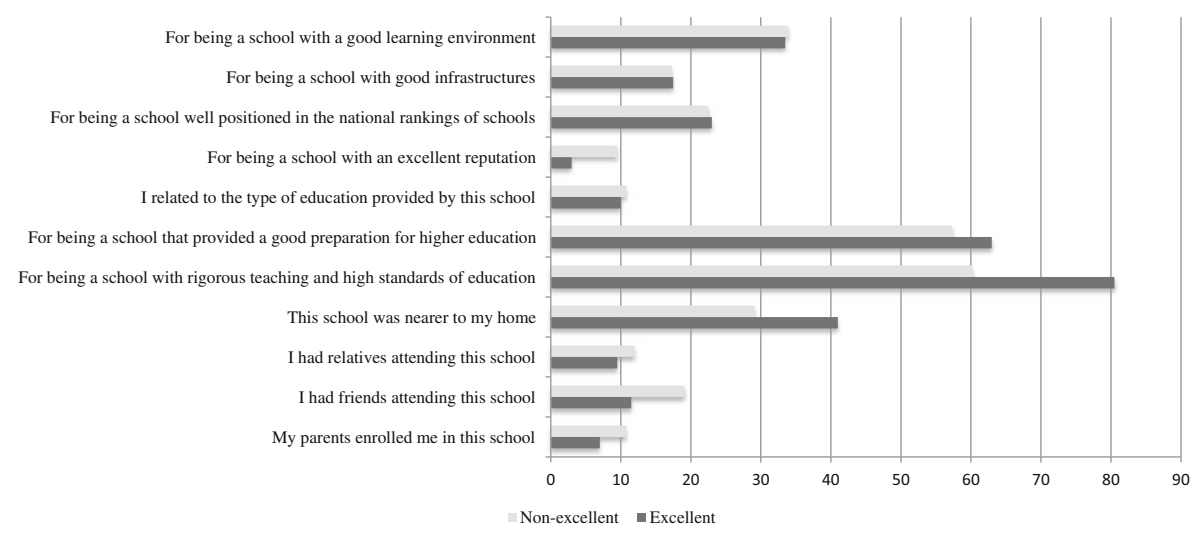

Fig. 2 Reasons for the school choice. Source: Surveys by questionnaire administered to excellent and nonexcellent students of 4 schools (2013/2014). Program used: Microsoft Excel for Mac 2011 
The data from the previous figure project a scenario somewhat dissonant compared with the perspective of the head teachers on the fabrication of a school image and its importance in the Portuguese education (quasi) market. In fact, from the list of reasons given here, the one that showed to be less conclusive for the choice of school was precisely the one that equated the "excellent social image" of the institution. Also, the place that it occupied on the national rankings does not seem to have gathered the first preferences of the students surveyed: it shows as the fifth most invoked reason, but denoting irrelevant differences among excellent and non-excellent students, without statistical significance when we consider the gender and social class variables, although the attendance in school 1 , and even in school 2, introduces a clear academic distinction in the preferences of students (see Fig. 3).

The supposed dissonance may, after all, be more apparent than real, being perhaps more indicative of an education market that is still inconsistent, but that gradually

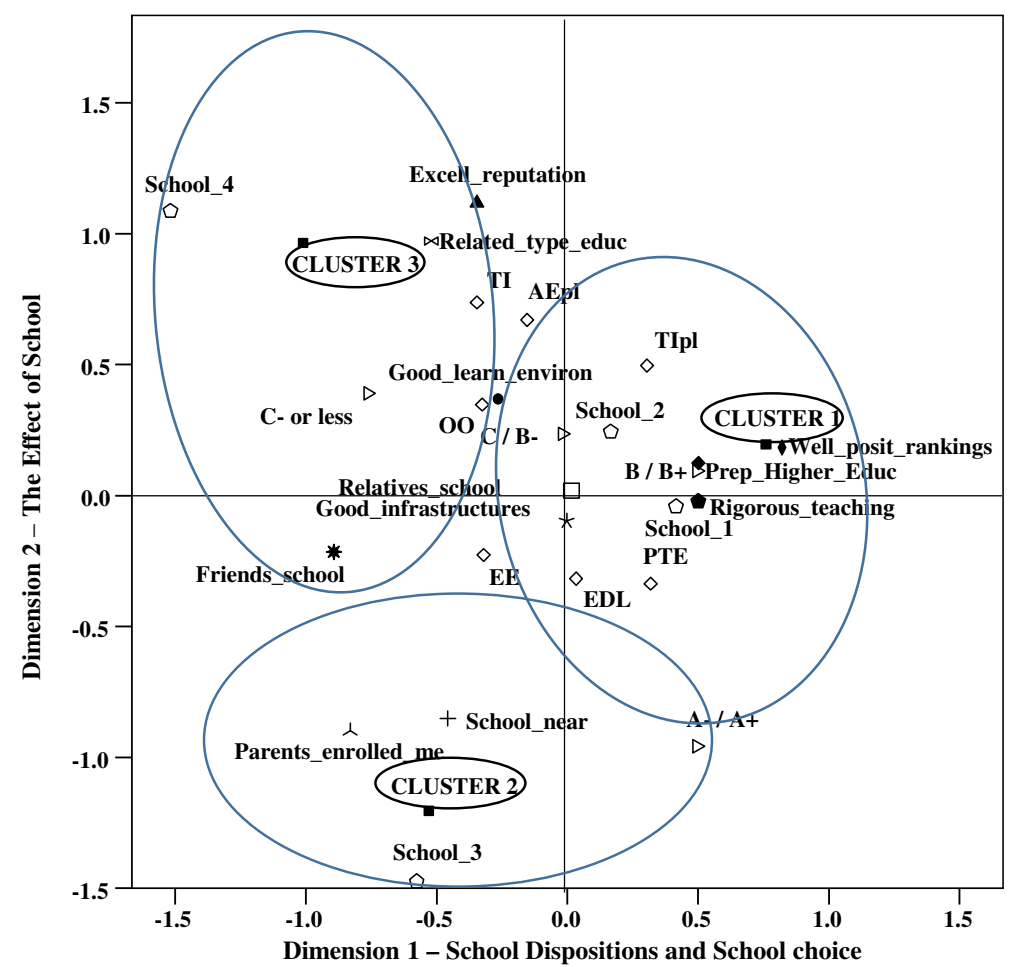

Fig. 3 Configuration of the school choice. Reasons for the school choice: [ $\bullet$ Cluster number of case (cluster 1, cluster 2, cluster 3); [॰] indicator of family's social class (EDL-entrepreneurs and executives; PTE—professionals and managers; TI, TIpl—self-employed and pluri-active self-employed; EE-routine employees; OO - industrial workers; AEpl—pluri-active farmers); [ $\square$ ] secondary school case study (school 1, school 2, school 3); $\left.{ }^{\triangleright}\right]$ secondary school's grade point average $(\mathrm{C}-$ or less; $\mathrm{C} / \mathrm{B}-; \mathrm{B} / \mathrm{B}+; \mathrm{A}-/ \mathrm{A}+)$; [ $]$ for being a school that provided a good preparation for higher education; [ $[$ ] for being a school well positioned in the national rankings of schools; [•] for being a school with a good learning environment; [ $\mathbf{\Delta}$ ] for being a school with an excellent reputation; [ $\star$ ] for being a school with good infrastructures; [ $]$ for being a school with rigorous teaching and high standards of education; [*] I had friends attending this school; [ $\square]$ I had relatives attending this school; [®] I related to the type of education provided by this school; [ ] my parents enrolled me in this school; [+] this school was nearer to my home. Program used: Export from IBM SPSS Statistics (v.24) as *.eps format and later edited on Microsoft PowerPoint for Windows 2013 
develops articulations among the various elements that compose it. It seems clear that, for head teachers, institutional marketing uses the test results as a lever for promoting the image of the school and the consequent attraction of students; in turn, for students and their families, the search for a school with rigorous teaching and high standards that provided good preparation for access to higher education functions as a projection based on the effects of socially constructed representations from the relative place of the institution in the school network and the identification with the social experiences shared in several networks of inter-knowledge.

Looking to explore an approach to the social space behind the choice of school, we performed a multiple correspondence analysis (MCA) using the software IBM SPSS Statistics (v. 23.0), whose plot resulting from the optimal scaling procedure can be seen in Fig. 3. We decided to retain three dimensions, having taken from their scores three clusters that we projected in plan $1 * 2$ of the MCA, as this provides a greater segmentation, and correlative cross-reading, on the reasons for the choice of school among the students surveyed. In this sense, two dimensions intersect in this plot which we call "school dispositions and school choice" (dimension 1) and "school effect" (dimension 2 ), with a respective inertia of 0.173 and 0.132 . The contribution of the first axis tends to emphasise a school choice guided by performance criteria, as opposed to a choice justified by pragmatism and sociability reasons. The discrimination provided by axis 2 highlights the specificity of schools whose educational dynamics turn away from, or do not focus on, the logics inherent to the production of results.

Three clusters resulted from this analytical exercise, with the reasons for the school choice summarised as follows: (i) cluster 1 (49.8\%) - school which provides a good preparation for higher education, with a demanding and quality education, well positioned in the rankings, attended by students from various socio-economic backgrounds, with emphasis on the parents being professionals and managers (technical and staff professionals - PTE), that is, parents who have professions based on a higher level of education. The two schools (school 1 and school 2) included in this cluster, attracting mainly students of the middle and upper middle class (more than $50 \%$ of the students fall in the PTE and EDL strata), are generally open to cultural and social diversity, so that academic results are not directly associated to the highest level of the scale; (ii) cluster $2(26.7 \%)$ - the most identified choices in this cluster refer to the proximity of the school in relation to the residence and the fact that it was the parents' decision to enrol them in that school. School 3 is the one that best fits this profile; of those studied, it is the one that presents a social composition more concentrated in the two more privileged social classes. The academic performance of the students allocated in this cluster is similar to that observed in cluster 1 with respect to the classifications at the A -/A+ level; (iii) cluster 3-by identifying themselves with the type of education provided in the school, the reputation and environment of the school, the fact that they have friends there, the students that comprise this cluster tend to attend school 4, a school that socially welcomes middle and popular classes, with academic performances that match the lower points of the scale in use.

In summary, having observed the head teachers' concern to disseminate an appealing school image, resorting to marketing strategies anchored in good academic performance, the data we discuss in this section indicate the dynamics of school choice articulated with representations that were built in the community about the school institution. To give an account (answerability) of school work to the community- 
especially student performance in national examinations and access to higher education-works as a "calling card" when the time comes for young people and families to decide, at a crucial moment, on the educational and professional pathway.

\section{Conclusion}

Throughout the text we demonstrate the expansion of the meritocratic ideology in Portuguese schools and/or school clusters through the adhesion of these educational institutions to the rituals of distinction and award of academic excellence, among other strategies to publicise the social image of the school. This movement differed from other historical periods, when the ideology of meritocracy prevailed. Nowadays, we are faced with a movement of (re)meritocracy which embraces new specificities such as the pressure of the families, or if we prefer, the power of parentocracy (Brown 1990). In synchrony with this movement, or as a result, in Portugal, there was a change in the governance model of schools under the pretext of overcoming the old bureaucraticprofessional logics of accountability and making the processes more transparent and congruent with the logic of new public management. The centrality of the manager, or the re-emergence of the "one-person" leadership model (head teacher), and the devaluation of collegiality in the administration of the state public school can be related with the growing democratic erosion in society in general and the concurrent ritualisation of the political, civic and educational participation processes (Lima 2011). The representation of the school, configured in a single entity, and the ease of communication and accountability with the State and the community were arguments that paved the way for such a change to materialise. Also, the increase of external pressure through the dissemination of the school rankings (by the mass media) and the external evaluation model, both overvaluing the academic performance of the students, brought to the surfaced an obsession with measurable results that created a technocratic evaluation (evaluocracy) without precedent. Without obeying to any guidelines imposed by the Ministry of Education, schools began to reposition themselves in the emerging educational market, restoring, for that purpose, distinction mechanisms for the best students which have become important pillars of the new educational marketing. Even though there are also ways of distinguishing students based on behaviours, attitudes and values, what is certain is that the vast majority of Portuguese schools have chosen to reward academic results only.

This meritocratic isomorphism observed in the universe of schools has become the cornerstone of an increasingly performative and recurrent management style which aims to the construction of a successful school image. Therefore, the observation of multiple forms of marketing, leveraged by school results but also complemented by institutional representation in the most varied community and media contexts, brought to the debate the need to think about new forms of accountability adjusted to the current educational realities. Even in a centralised educational system, such as the Portuguese, where schools enjoy reduced autonomy, we notoriously observed many forms of distinction of the best students as well as their use as a device to improve school success.

Predominating the organisational configuration of the school clusters (by grouping schools of different degrees of education), the award ceremonies of honour and excellence (at all levels of education) are celebratory moments open to the community 
which aim to consolidate the identity and the pedagogical virtuousness of these school clusters. It is true that in a territory where there are several school clusters, these ceremonies have all the more force and social impact the greater the number of distinguished students. However, the award of merit was also visible in schools and/ or school clusters not included in competitive territories, since they were the only existing educational alternative. In these cases, the performative level of students converges more towards the recognition of the school's educational project and its leadership than to the construction of a school image with merely competitive ends.

In the wake of recent theoretical proposals, we agree with the notion of "multiple forms of accountability" (Schillemans 2015; Pollock and Winton 2016), in relation to which the proposal of educational marketing accountability gains sense. For example, in the construction of school excellence based on measurable academic results, and given the central role of the school or school cluster head teacher, we are facing a partial form of accountability (managerial accountability), which does not cease to have a relationship with other partial forms, as it is required by civil society (social accountability) or, more consistent with the empirical data presented in this article, the one that induces school choice by publicising the performance of their best students (marketing accountability).

Students and those responsible for the management of schools take the leading role in a new educational reality, which we call neo-meritocratic. The actions of these central actors are now converging and mutually reinforcing. To put it another way, the performance and academic success of some (students) is highly functional for an educational system whose institutional managers (head teachers) intentionally assume merit recognition as one of the strategies for the management of differences and inequalities. Because it is a state school, it is complex in organisational terms and plural in its audiences and in its mandates. We can now, as a conditional synthesis, confront the implementation plan of a common cultural minimum and, simultaneously, the utopia of the appreciation of the plurality of excellences (expressed by Collège de France / and Bourdieu 1985), with the evolution of the Portuguese post-democratic revolution educational reality. In recent decades, we have invested a great deal in terms of access to basic education for everyone, but many of the goals for a greater equity in the success and continuity of the school paths still remain to be achieved. At the same time, however, society tends to accept, without visible resistance, the increasing (neomeritocratic) selectivity in secondary education. It is this level of education that again takes the institutional place of the construction of unidimensional excellence, delaying, by many decades of uncertainty, the inscription of recognition, more just and democratic, on the political agenda, of a plurality of excellences.

Funding This work is funded by CIEd - Research Centre on Education, projects UID/CED/1661/2013 and UID/CED/1661/2016, Institute of Education, University of Minho, through national funds of FCT/MCTES-PT.

\section{References}


Afonso, A. J. (2010b). Um olhar sociológico em torno da accountability em educação. In M. T. Esteban \& A. J. Afonso (Eds.), Olhares e interfaces. Reflexões críticas sobre a avaliação (pp. 147-170). São Paulo: Cortez Editora.

Afonso, A. J. (2014). The emergence of accountability in the Portuguese education system. European Journal of Curriculum Studies, 1(2), 125-132.

Antunes, F., \& Sá, V. (2010). Públicos escolares e regulação da educação. Lutas concorrenciais na arena educativa. Vila Nova de Gaia: Fundação Manuel Leão.

Ball, S. (2000). Performativities and fabrications in the education economy: towards the performative society? Australian Educational Researcher, 27(2), 1-23.

Bardin, L. (1977). L'analyse de contenu. Paris: PUF.

Baroutsis, A. (2016). Media accounts of school performance: reinforcing dominant practices of accountability. Journal of Education Policy, 31(5), 567-582.

Blackmore, P. (2016). Prestige in academic life. Excellence and exclusion. London and New York: Routledge.

Brown, P. (1990). The "third wave": education and the ideology of parentocracy. British Journal of Sociology of Education, 11(1), 65-86.

Collége de France /, \& Bourdieu, P. (1985). Propositions pour l'enseignement de l'avenir/ Rapport au Président de la République par le Collège de France. Paris: Collège de France.

Cortesão, L., Stoer, S., Antunes, F., Araújo, D., Macedo, E., Magalhães, A., et al. (2007). Na girândola de significados. Polissemia de excelências em escolas portuguesas do século XXI. Porto: Livpsic.

Daverne, C., \& Dutercq, Y. (2008). L'implication des responsables d'établissement dans la formation scolaire des élites. Education et Sociétés, 21(1), 33-47. https://doi.org/10.3917/es.021.0033.

Daverne, C., \& Dutercq, Y. (2013). Les bons élèves. Expériences et cadres de formation. Paris: PUF.

Dench, G. (Ed.). (2006). The rise and rise of meritocracy. Oxford: Blackwell Publishing.

Derouet, J.-L., Normand, R., \& Pacheco, R. (2015). La modernización del sistema educativo en Francia: La nueva gestión pública entre la afirmación del Estado y la governanza descentralizada. Educação $e$ Sociedade, 36(132), 723-741.

Duru-Bellat, M. (2009). Le mérite contre la justice. Paris: Presses de Sciences Po.

Dutercq, Y. (2015). Les modèles contemporains de légitimité des chefs d'établissement français. Recherche \& formation, (78, 1), 35-50.

Dutercq, Y. (2016). Accountability, una caja de herramientas, no una política: El caso del sistema educativo francés. Profesorado, Revista de Currículum y Formación del Profesorado, 20(3), 145-169 Retrieved from https://recyt.fecyt.es/index.php/profesorado/issue/view/2929. Accessed 18 Oct 2017.

Dutercq, Y., \& Daverne, C. (2009). Les parcours composites de l'élite lycéenne Comment se préparer pour un monde incertain? Les Sciences de l'Éducation - Pour l'Ère nouvelle, 42(4), 17-37. https://doi.org/10.3917 /sdle.424.0017.

Dutercq, Y., \& Maroy, C. (2014). Le développement des politiques d'accountability et leur instrumentation dans le domaine de l'éducation: une perspective franco-canadienne. Revue Education Comparée, 11, 7-30. Retrieved from: https://rive.google.com/file/d/0B9H69s41Qe_jNm53eEdpQVhhRlE/view?ts=56c9e306. Accessed 18 Oct 2017.

Grek, S. (2009). Governing by numbers: the PISA 'effect' in Europe. Journal of Educational Policy, 24(1), $23-37$.

Grek, S., \& Ozga, J. (2010). Governing education through data: Scotland, England and the European educational policy space. British Educational Research Journal, 36(6), 937-952.

Grek, S., Lawn, M., Lingard, B., Ozga, J., Rinne, R., Segerholn, C., \& Simola, H. (2009). National policy brokering and the construction of the European education space in England, Sweden, Finland and Scotland. Comparative Education, 45(1), 5-21.

Hardy, I. (2015). Data, numbers and accountability: the complexity, nature and effects of data use in schools. British Journal of Educational Studies, 63(4), 467-486.

Law no. 51/2012, (2012) of 5 September. Diário da República, $n .^{\circ}$ 172/2012, I. ${ }^{\text {a }}$ Série.

Lawn, M. (2011). 'Voire' comme l'état: La gouvernance contemporaine de l'éducation en Angleterre. Éducation et Société, 28(2), 65-76.

Legislative Order no. 102/90, of 12 September. Diário da República, $n .^{\circ} 211 / 90-I{ }^{a}$ Série.

Legislative Order no. 5908/2017, (2017) of 5 July. Diário da República, $n{ }^{\circ}{ }^{128 / 2017}$, II. ${ }^{a}$ Série.

Legislative Order no. 6173/2016, (2016) of 10 May. Diário da República, $n .^{\circ}$ 90/2016 - II. ${ }^{\text {a }}$ Série.

Lima, L. C. (2011). Administração escolar: Estudos. Porto: Porto Editora.

Magalhães, A., \& Stoer, S. (2002). A escola para todos e a excelência académica. Maia: Profedições.

Maxwell, C., \& Aggleton, P. (Eds.). (2016). Elite education. International perspectives. London. New York: Routledge.

McNamee, S., \& Miller, R., Jr. (2004). The meritocracy myth. Oxford: Rowman \& Littlefield Publishers, Inc. 
Meuret, D. (2012). Les effets de la régulation par les résultats (accountability) sur les politiques d'éducation aux États-Unis. Education et Sociétés, 30(2), 75-87.

Michaud, Y. (2009). Qu'est-ce que le mérite. Paris: Bourin Éditeur.

$\mathrm{Ng}$, P. T. (2010). The evolution and nature of school accountability in the Singapore education system. Educational Assessment, Evaluation and Accountability, 22(4), 275-292.

Nunes, J. A., Matias, M., Costa, S., Correia Jesuino, J., Carvalho, S., \& Diego, C. (2003). "Public accountability": the Portuguese "landscape. Oficina do CES, 198, 1-46 Retrieved from: http://ces.uc.pt/pt/publicacoes/outraspublicacoes-e-colecoes/oficina-do-ces/numeros/oficina-198. Accessed 18 Oct 2017.

Order no. 13173-C/2011, (2011) of 30 September. Diário da República, $n{ }^{\circ} 189 / 11$ - II. ${ }^{\text {a }}$ Série.

Order no. 20513/2008, (2008) of 5 August. Diário da Republica, $n .^{\circ}$ 150/2008 - II. ${ }^{a}$ Série.

Palhares, J. A., \& Torres, L. L. (2015). School governance and academic excellence: The representations of distinguished students in an annual award of excellence. Journal of Educational, Cultural and Psychological Studies (ECPS), 11, 277-292. https://oi.org/10.7358/ecps-2015-011-palh.

Palhares, J. A., \& Torres, L. L. (2017). L'expansion de la culture méritocratique et la formation des élites dans l'école publique portugaise. In J.-L. Derouet, H. Yiping, P. Savoie, \& J.-É. Charlier (Eds.), La formation des élites en Chine et en France (XVII ${ }^{-}$-XXI ${ }^{e}$ siècles). Les apports de regards croisés: Sociologie, histoire, philosophie politiques. (pp. 113-130). Louvain-la-Neuve: Éditions L'Harmattan.

Parcerisa, L., \& Verger, A. (2016). Rendición de cuentas y política educativa: Una revisión de la evidencia internacional y futuros retos para la investigación. Profesorado, Revista de Currículum y Formación del Profesorado, 20(3), 15-51 Retrieved from https://recyt.fecyt.es/index.php/profesorado/issue/view/2929. Accessed 18 Oct 2017

Pollock, K., \& Winton, S. (2016). Juggling multiple accountability systems: how three principals manage these tensions in Ontario, Canada. Educational Assessment, Evaluation and Accountability, 28(4), 323-345.

Quaresma, L. (2010). Da escola pública ao colégio privado: entre a homogeneidade perdida e a homogeneidade reivindicada. Sociologia da Educação. Revista Luso-Brasileira, 2, 72-101 Retrieved from: http://www. maxwell.lambda.ele.puc-rio.br/rev_sociologia_edu.php?strSecao=input0. Accessed 18 Oct 2017

Schillemans, T. (2015). Managing public accountability: how public managers manage public accountability. International Journal of Public Administration, 38, 433-441.

Tenret, E. (2011). L'école et la méritocratie. Représentations sociales et socialisation scolaire. Paris: PUF.

Torres, L. L. (2004). Cultura organizacional em contexto educativo. Sedimentos culturais e processos de construção do simbólico numa escola secundária. Braga: Centro de Investigação em Educação da Universidade do Minho.

Torres, L. L. (2014). A ritualização da distinção académica: O efeito cultura de escola. In L. L. Torres \& J. A. Palhares (Orgs.), Entre mais e melhor escola em democracia. A inclusão e a excelência no sistema educativo português (pp. 33-56). Lisboa: Mundos Sociais.

Torres, L. L. (2015). Culturas de escola e celebração da excelência: Cartografia das distinções em Portugal. Educação e Pesquisa, 41(Special number), 1419-1438.

Torres, L. L., \& Quaresma, M. L. (2017). The meritocratic ideal in education systems: The mechanisms of academic distinction in the international context. Education as Change, 21(1), 13-30.

Torres, L. L., Palhares, J. A., Rocha, C., \& Lima, L. C. (2014). Le directeur: Modèle de gestion et de leadership dans l'école publique portugaise. In J.-L. Derouet \& R. Normand (Eds.), La question du leadership en éducation. Perspectives européennes (pp. 195-217). Louvain-La-Neuve: AcademiaL'Harmattan s.a.

Van Zanten, A., Ball, S., \& Darchy-Koechlin, B. (Eds.). (2015). Elites, privilege and excellence. The national and global redefinition of educational advantage. New York and London: Routledge.

Verger, A., \& Curran, C. (2014). New public management as a global education policy: its adoption and recontextualization in a Southern European setting. Critical Studies in Education, 55(3), 253-271.

Verger, A., \& Normand, R. (2015). Nueva gestión pública y educación: elementos teóricos y conceptuales para el estúdio de un modelo de reforma educativa global. Educação e Sociedade, 36(132), 599-622.

Vieira, M. M., Pappámikail, L., \& Resende, J. (2013). Forced to deal with the future: uncertainty and risk in vocational choices among Portuguese secondary school students. Sociological Review, 61, 745-768.

Ward, S. C. (2012). Neoliberalism and the global restructuring of knowledge and education. New York and London: Routledge.

Young, M. (2008). The rise of the meritocracy (11th ed.). New Brunswick and London: Transaction Publishers.

Publisher's note Springer Nature remains neutral with regard to jurisdictional claims in published maps and institutional affiliations. 